\title{
Vibroseismic protection of heavy mining machines, buildings and structures
}

\author{
Vitalii Dyrda ${ }^{1, *}$, Anatolii Kobets ${ }^{2}$, Ievgeniia Bulat ${ }^{3}$, Vladimir Lapin ${ }^{4}$, Natalia Lysytsia ${ }^{5}$, \\ Hennadii Ahaltsov", and Serhii Sokol ${ }^{2}$ \\ ${ }^{1}$ Institute of Geotechnical Mechanics named by N. Poljakov of National Academy of Sciences of \\ Ukraine, 49005, Dnipro, Simferopolska Str., 2a, Ukraine \\ ${ }^{2}$ Dnipro State Agrarian and Economic University, 49600, Dnipro, Serhiia Yefremova Str., 25, \\ Ukraine \\ ${ }^{3}$ Pridneprovsk Scientific Center of NAS of Ukraine and Ministry of Education and Science of \\ Ukraine, 49600, Dnipro, Lyashka-Popelya Str., 15, Ukraine \\ ${ }^{4}$ Kazakh Research and Design Institute of Construction and Architecture, 050036, Almaty, 3rd \\ microdistrict, 45/1, Kazakhstan \\ ${ }^{5}$ Oles Honchar Dnipro National University, 49010, Dnipro, Haharina Ave., 72, Ukraine
}

\begin{abstract}
In the article, the authors analyze main issues of protecting buildings and structures against vibroseismic effects with the help of system of elastomeric blocks, which are characterized by high vertical stiffness, low shear stiffness, high energy dissipation and ability to center vertical load; besides, they feature high reliability with no risk of sudden failure. Results of static and dynamic tests of parametric series of elastomeric blocks used for protection of residential buildings against vibrations are presented. Design of pile with anti-vibration rubber supports is described. Calculation of elastomeric blocks under static compression is presented. Components of the stress-strain state of the thin-layer elements were investigated, and rate of the thin rubber layer compression under the action of vertically applied force was calculated. In numerical calculation, weak compressibility of rubber was simulated by moment force of the finite element for weakly compressible materials, which assumes triple approximation of displacement fields, deformation components, and volume change function. The numerical solution was obtained by the finite element method for different radius-thickness ratios in case of geometrically nonlinear elastic and viscoelastic deformation.
\end{abstract}

\section{Preface}

Analysis of global practice of vibroseismic protection of buildings and structures shows that systems with elastomeric blocks are the most promising in terms efficiency. In case of seismic movements, these systems protect buildings and structures not only in vertical and horizontal planes, but also against torsion.

Protection of heavy mining machines (screens, vibratory feeders, cone inertial crushers, vibroconveyors, crushers, etc.) against vibration action with the help of rubber vibroseismic

${ }^{*}$ Corresponding author: vita.igtm@gmail.com 
insulators is described in all details in [1].

System of vibration and seismic action insulation (vibroseismic protection system) is designed to reduce seismic response of the buildings and protect them against earthquakes. The system can also be used to protect construction sites from industrial vibrations and shock waves, such as waves caused by explosions in the quarries and vibrations and noise caused by subway, motor and rail transports $[2-5,12]$. Use of vibroseismic protection in Ukraine is regulated by European and Ukrainian regulatory documents [6].

For the purpose of practical application of vibroseismic protection systems in the buildings, Institute of Geotechnical Mechanics named by N. Poljakov of National Academy of Sciences of Ukraine and the state enterprise "Research Institute of Building Structures" carried out experimental studies and substantiated parameters of rubber blocks for seismic protection (rubber seismic blocks - RSB), patented their designs, developed design documentation and made experimental samples of three diameters $(340 \mathrm{~mm}, 400 \mathrm{~mm}$ and $500 \mathrm{~mm}$ ) and with the following heights of the rubber layer: $50 \mathrm{~mm}, 2 \times 120 \mathrm{~mm}, 2 \times 70 \mathrm{~mm}$ and $2 \times 50 \mathrm{~mm}$. The RSB experimental samples (Fig. 1) were manufactured by the Ukrainian enterprises.

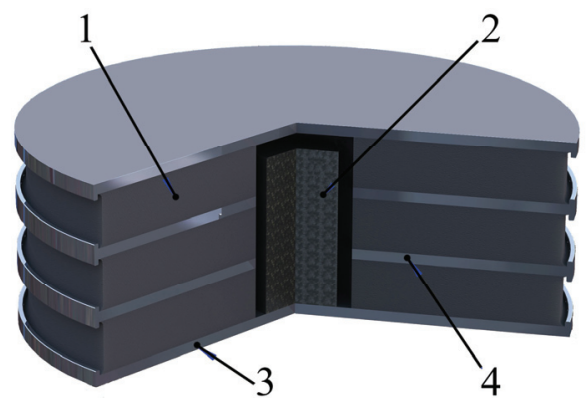

Fig. 1. General view of rubber-metal highly-damping anti-vibration and anti-seismic support with the lead core: 1 - rubber layer; 2 - lead core; 3 - bed plate; 4 - metal plate with a fillet.

In order to determine stiffness and damping characteristics of elastomeric blocks for industrial conditions, the state enterprise "Research Institute of Building Structures" conducted laboratory tests of three types of the designed blocks under static and dynamic loads in accordance with requirements of Eurocode 8, European and international standards.

Objective of the work - based on the results of static and dynamic tests of rubber seismic modules, develop method for calculating them.

\section{Designing of System for Seismic Insulation according to the SCN V.1.1-12:2014 standard}

Section SCN V.1.1-12:2014 of the Ukrainian standard contains general provisions for designing systems for seismic insulation of buildings and structures of different functioning. In this article, passive system of the building and structure seismic insulation with no additional sources of energy for oscillation damping is considered.

Seismic insulation system is used in buildings of different functioning when new buildings are constructed or existing ones are reconstructed. The seismic insulation system should be located under the great bulk of the construction, as a rule, between foundation and upper part of the building (superstructure).

Seismic insulation systems should feature: high vertical stiffness; low shear stiffness in order to improve effectiveness of horizontal seismic insulation; ability to produce essential 
horizontal displacements during the earthquakes; great energy dissipation; limited horizontal displacements at non-seismic loads; high reliability with no chance for failure; high level of engineering equipment protection with no risk to damage bearing elements.

Seismic protection means improvement of building and structure seismic resistance thanks to special structural elements, which can withstand the calculated seismic loads without complete destruction and with minimal loss of life.

Seismic protection allows to: keep the building and structure integrity during earthquakes and man-made impacts; cut down the estimated costs of construction; reduce material consumption for the buildings and structures; decrease labour intensity of the construction; expand area of standard series application due to development of areas with high risk of seismicity and increased number of stories in buildings constructed with the same structures.

\section{Methods}

\subsection{Results of experimental studies}

Method of the experimental study is described in [1]; and results of the study of rubber element compression and shear are described in [5].

In order to determine effect of lead core on the RSB stiffness and damping characteristics (rubber elements with diameter of $500 \mathrm{~mm}$ were tested) two supports without lead cores and two - with lead cores were tested in cyclic mode for compression and shearing. The cores were made in the form of solid cylinders with height of $100 \mathrm{~mm}$ and diameter of $70 \mathrm{~mm}$.

Figure 2 shows the "horizontal load - displacement" dependencies for the RSB with lead core (curve 1) and without the core (curve 2) under vertical load of $1000 \mathrm{kN}$ on the support. Analysis of the graphs shows that, at shear, lead core significantly affects the RSB stiffness and dissipative characteristics.

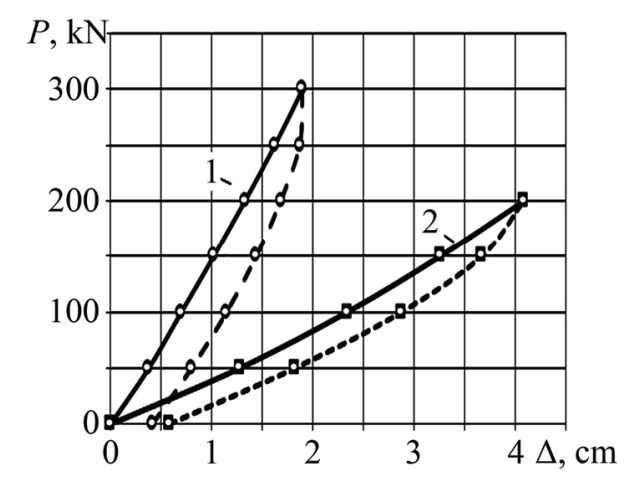

Fig. 2. The "loading-unloading" dependencies for the RSB with diameter $500 \mathrm{~mm}$.

Tests for support compression were conducted with three types of supports - diameter $400 \mathrm{~mm}$, height: $2 \times 70 \mathrm{~mm}$ and $2 \times 120 \mathrm{~mm}$; and diameter $500 \mathrm{~mm}$, height $2 \times 50 \mathrm{~mm}$.

In accordance with requirements of the ISO (International Organization for Standardization) standard and European standard, and in order to determine state of the RSB design at maximum vertical loads 4 times higher than the design load, one RSB sample was tested under cyclic vertical loads by special program: three half-cycles "loading-unloading" each time adding $300 \mathrm{kN}$ (exposure at each stage was for 5 minutes) up to $3000 \mathrm{kN}$; two half-cycles "loading-unloading" each time adding $500 \mathrm{kN}$ (exposure at 
each stage was for 2 minutes) up to $5000 \mathrm{kN}$; and 1 half-cycle "loading-unloading" gradually adding $1000 \mathrm{kN}$ (exposure at each stage was for 5 minutes) up to $9000 \mathrm{kN}$.

With the compression multi-cyclic loads from $3000 \mathrm{kN}$ to $9000 \mathrm{kN}$, after the RSB complete unloading for 10 minutes, rubber elements totally took their original shape. No cracks were found in any of the 12 tested rubber elements made of natural rubber.

\subsection{Technical solutions and installation of the RSBs}

The seismic blocks are manufactured on the rubber elements of the target dimension. With the help of results of calculation of seismically insulated building in terms of seismic loads, geometric parameters of the rubber elements and their compression and shear stiffness were determined. The seismic blocks were installed between the lower base plate (for example, on its ribbed stiffeners) and the upper monolithic reinforced concrete distributing plate of the building (Fig. 3). It is also possible to install the RBS on the basement floor or on the pile head. The lower support plate can be bolted by the anchors to the ribs of the foundation slab or to the pile head, and the upper support plate can be fastened to the upper distributing concrete plate of the building or to the monolithic walls of the basement floor.

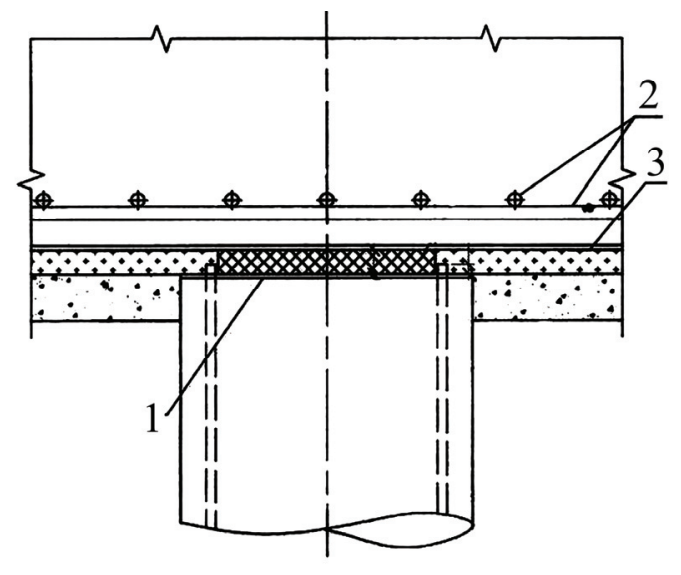

Fig. 3. Layout of RSB on a pile of the anti-vibration system in sections 1 and 2 of the apartment house in the Kikvidze street, city of Kyiv: 1 - RSB; 2 - lower reinforcement of the grillage; 3 polyethylene film.

\subsection{Calculation of RSB}

Calculation of the rubber element was considered in [8-11]. For small deformations $(\varepsilon<0.1)$, and with the help of the Ritz method, the authors of this work obtained an analytical dependency between compression $\Delta$ of cylindrical rubber layer with free (unfastened) top and bottom and the applied load:

$$
\Delta=\frac{P_{0} h}{3 \pi R^{2} G}\left[1-\frac{R}{h \sqrt{6}} \text { th } \frac{h \sqrt{6}}{R}\right],
$$

where $P_{0}$ is compressive load on the rubber layer with free top and bottom, $\mathrm{N} ; h$ is height of the rubber layer, $\mathrm{m} ; R$ is radius of the rubber layer, $\mathrm{m}$; and $G$ is the rubber shear modulus, $\mathrm{Pa}$.

At uniaxial compression and small deformations $(\varepsilon<0.1)$, dependency between the rubber layer compression and applied load is determined by the formula: 


$$
\Delta=\frac{P_{0} h}{3 \pi R^{2} G}
$$

Calculations of seismic supports should take into account the fact that top and/or bottom of the rubber layer can be vulcanized into the metal plates; in this case, in formulas (2) and (3), load $P_{0}$ should be substituted by the corrected value of real load $P$, which takes into account increased stiffness due to the fastened top and/or bottom:

$$
P_{0}=P / \beta,
$$

where $\beta=1+0.413 \rho^{2}-$ according to Payne; $\beta=0.92+0.5 \rho^{2}-$ according to Lavendelis.

The authors propose to calculate $\beta$ by the following formula:

$$
\beta=1+0.83 \rho^{2},
$$
bottom.

where $\rho=R / h, \beta$ is coefficient of the stiffness increase due to the fastened top and/or

Method of finite element (FEM) is the universal numerical method for calculating rubber vibro- and seismic insulators as it allows to take into account asymmetry of loads and fastening, as well as to obtain an overall picture of the stress-strain state. At the same time, traditional FEM does not allow to consider such property of rubber as weak compressibility of the material; therefore, the authors use a specially developed FEM scheme - a finite element moment scheme (FEMS) for weakly compressible materials. This scheme assumes triple approximation of displacement vector components, deformation tensor components and volume change function, and stabilization of some of the summands according to certain rules. For a prismatic finite element of a triangular shape, these approximations take the following form:

$$
\begin{gathered}
u_{k^{\prime}}=\sum_{p q r}^{l m n} \omega_{k^{\prime}}^{(p q r)} \psi^{(p q r)}=\omega_{k^{\prime}}^{(000)}+\omega_{k^{\prime}}^{(100)} \psi^{(100)}+\omega_{k^{\prime}}^{(010)} \psi^{(010)}+\omega_{k^{\prime}}^{(110)} \psi^{(110)}+ \\
+\omega_{k^{\prime}}^{(001)} \psi^{(001)}+\omega_{k^{\prime}}^{(101)} \psi^{(101)} ; \\
\varepsilon_{11}=e_{11}^{(000)}+e_{11}^{(010)} \psi^{(010)}+e_{11}^{(001)} \psi^{(001)} ; \varepsilon_{22}=e_{22}^{(000)}+e_{22}^{(100)} \psi^{(100)} ; \varepsilon_{33}=e_{33}^{(000)}+e_{33}^{(100)} \psi^{(100)} ; \\
\varepsilon_{12}=e_{12}^{(000)} ; \varepsilon_{13}=e_{13}^{(000)} ; \varepsilon_{23}=e_{23}^{(000)}+e_{23}^{(100)} \psi^{(100)} ; \theta=e_{11}^{(000)} g^{11}+e_{22}^{(000)} g^{22}+e_{33}^{(000)} g^{33},
\end{gathered}
$$

where $u_{k^{\prime}}$ are components of displacement vector in the direction of the $k^{\prime}$ axis of the basic coordinate system; $\varepsilon_{i j}$ are components of deformation tensor; $\theta$ is volume change function; $l, m, n$ are maximum degrees of approximating polynomials relatively to the axes of the local coordinate system $x_{1}, x_{2}, x_{3} ; g^{i j}$ are components of metric tensor; $\omega_{k^{\prime}}^{(p q)}$ are coefficients of displacement decomposition; $e_{i j}^{(p q r)}$ are coefficients of deformation decomposition; $\psi^{(p q r)}$ is a set of power coordinate functions of the form:

$$
\psi^{(p q r)}=\frac{\left(x_{1}\right)^{p}}{p !} \frac{\left(x_{2}\right)^{q}}{q !} \frac{\left(x_{3}\right)^{r}}{r !} .
$$

In order to improve accuracy of the calculations, the improved FEMS schemes [9] are 
used.

Let's find compression $\Delta$ for the two-layer seismic support with diameter $d=400 \mathrm{~mm}$, height of the rubber layer $h=240 \mathrm{~mm}$ and modulus of elasticity $G=0.63 \mathrm{MPa}$; the compression is caused by load $P=50 \mathrm{kN}$.

Solution for the nonlinear problem of solid cylinder compression with taking into account specific stiffness on the top and/or bottom was found numerically by the Runge-Kutta method with the fourth-order accuracy. To this end, it was necessary to solve the Cauchy problem with certain boundary conditions. As a result of calculations, a value of seismic insulator compression $\Delta=0.0127 \mathrm{~m}$ was obtained, which well coincided with results of experimental studies.

The problem was also implemented numerically on the basis of the finite element moment scheme. In Figure 4, distribution of stress tensor components in the seismic support is shown:

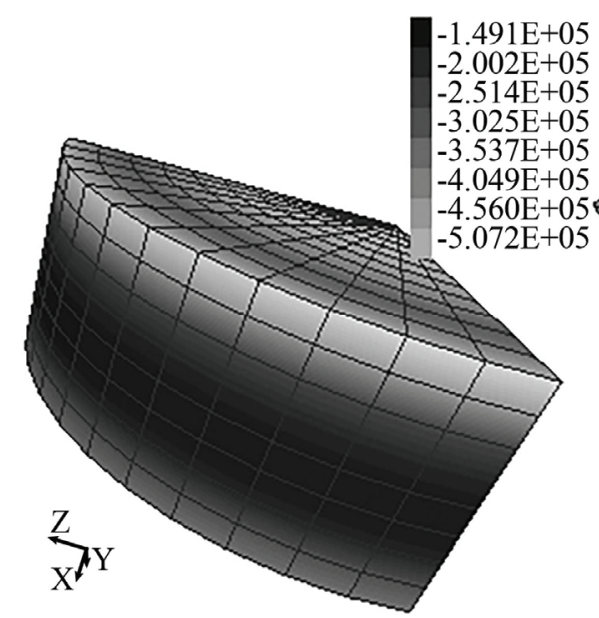

a) $\sigma_{x x}$

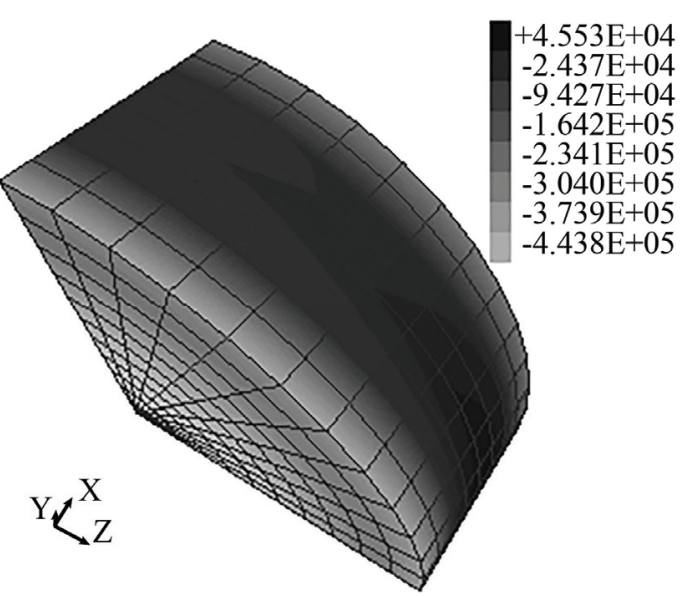

b) $\sigma_{y y}$

Fig. 4. Distribution of normal stresses in the seismic support.

Results of calculation of the vibration insulator compression at $\beta=2.38$ (by formula (4)) are shown in Table 1.

Table 1. Results of calculation of seismic support compression.

\begin{tabular}{|c|c|c|c|c|}
\hline \multirow{3}{*}{ Index } & \multicolumn{4}{|c|}{ Method for calculating compression } \\
\hline & \multirow{2}{*}{$\begin{array}{l}\text { experimental } \\
\text { studies }\end{array}$} & \multicolumn{2}{|c|}{ formulas } & \multirow{2}{*}{$\begin{array}{c}\text { numerical } \\
\text { implementation }\end{array}$} \\
\hline & & (1) & (2) & \\
\hline $\begin{array}{l}\text { Compression (maximum deflection of } \\
\text { the rubber element })(\mathrm{m}) \text { : }\end{array}$ & 0.0127 & 0.0084 & 0.0128 & 0.01128 \\
\hline
\end{tabular}

It is evidently that the most accurate result was obtained by formula (2), however, this formula does not provide an overall picture of the stress-strain state distribution in seismic support unlike the numerical implementation and the Ritz method.

\section{Conclusions}

1. A method has been developed for calculating rubber seismic blocks for vibroseismic protection of machines, buildings and structures.

2. The designed and tested RSB were used in 2014-2018 for seismo- and vibration 
protection (caused by underground trains and motor transport) of residential buildings in Kyiv: 10-section 10-storey residential building in the Kikvidze street and three 27-storey residential buildings in the Obolonskyi Avenue (Fig. 5), plus three houses in Lviv.

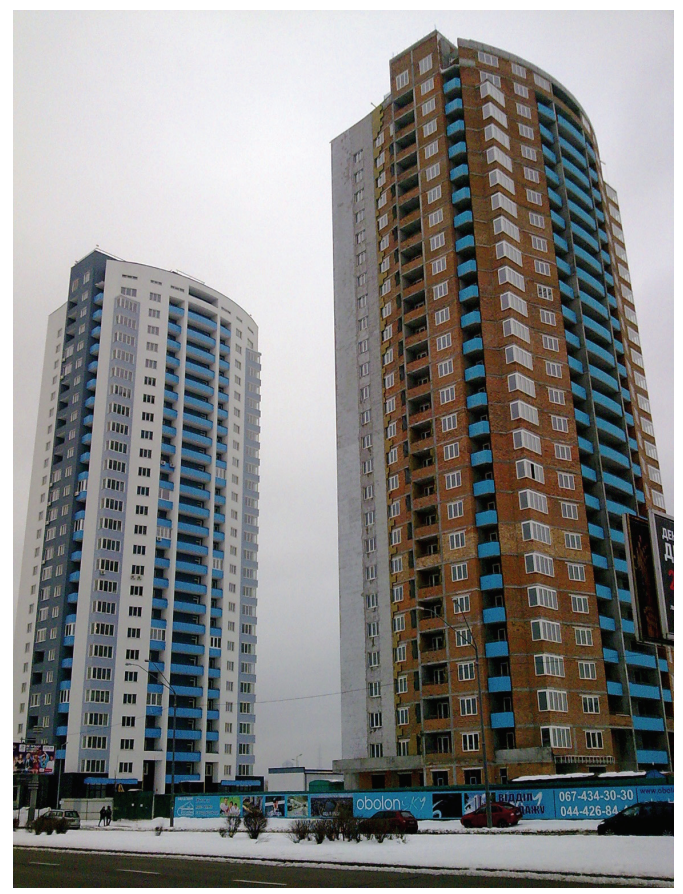

Fig. 5. General view of residential houses in Obolonskyi avenue in Kyiv with the system of vibration protection (distance to the shallow underground line is $100 \mathrm{~m}$ ).

3. Seismic insulation based on the RSB provides intrinsic oscillation frequency of the building in horizontal plane at the level of $1 \mathrm{~Hz}$ and less being in harmony with requirements of the SCN standard and Eurocode 8 on designing systems for seismic insulation of buildings. It should be noted that the designed RSB can be also used to protect buildings and structures against effects of ground (rail and motor transport) and underground (trains) transport, and for insulation of vibration of various heavy machines to ensure safety functioning of buildings and structures.

\section{References}

1. Bulat, A.F., Dyrda, V.I., Zviagilskii, E.L. Kobets, A.S. (2012). Prikladnaya mekhanika uprugo-nasledstvennykh sred. Tom 2. Metody rascheta elastomernykh detalei [Applied mechanics of elastic-hereditary media. Vol. 2. Design techniques of elastomeric parts]. Kyiv: Naukova dumka

2. J.M. Kelly. Seismic insulation systems for developing countries, Earthquake Spectra, 3 18 (2002)

3. Smirnov, V.I. (2009). Tests of highly damping rubber supports for use in seismic insulated building "Hotel and tourist complex "Sea Plaza" in Sochi, Seysmostoykoye stroitelstvo. Bezopasnost sooruzheniy, 4, 40-48

4. Nemchinov, Yu.I. (2008). Seismostoykost zdaniy i sooruzheniy [Seismohundred-bone of buildings and constructions]. Kyiv: Gudimenko

5. Bulat, A.F., Nemchinov, Yu.I., Dyrda, V.I. (2009). The rubber-metallic blocks for vibro-seismic safety of machines and constructions, Galuzeve mashynobuduvannya, 
budivnytstvo, 3 (25), 1, 30-35

6. Ministerstvo rehionalnoho rozvytku ta budivnytstva Ukrayiny. (2014). DBN V.1.112:2014. Stroitelstvo $v$ seysmicheskikh rayonakh Ukrainy [SCN V.1.1-12:2014. Construction in seismic regions of Ukraine]

7. Dyrda, V.I., Nemchinov, Yu.I., Lysytsia, M.I., Marienkov, M.H., Puhach, A.M., Zharko, L.O. (2011). Antiseismichna opora. Patent No 58418, Ukraine

8. Biderman, V.L. (1968), Calculation of cylindrical and rectangular long rubber shock absorbers, Raschety na prochnost [Strength calculations], 13, 55-72

9. Grebeniuk, S.N., Bova, A.A. (2009). Increase of accuracy of the moment diagram of a finite element for weakly compressible materials, Sovremennyye problemy i puti ikh resheniya v nauke, transporte, proizvodstve i obrazovanii [Modern problems and ways of their solution in science, transport, production and education], (22), 55-64

10. Kirichevskiy, V.V. (2002). Metod konechnykh elementov v mekhanike elastomerov. Kyiv: Naukova dumka

11. Bulat, A.F., Dyrda, V.I., Lysytsya, M.I., Grebenyuk, S.M. (2018). Numerical Simulation of the Stress-Strain State of Thin-Layer Rubber-Metal Vibration Absorber Elements Under Nonlinear Deformation, Strength of Materials, 3 (50), 387-395

12. Cherepinsky, Yu.D., Lapin, V.A. (1995). Fundamentals of Seismic Isolation in Construction. Irkutsk: ELITE Publishing House 